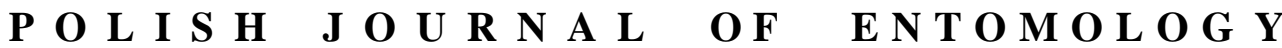

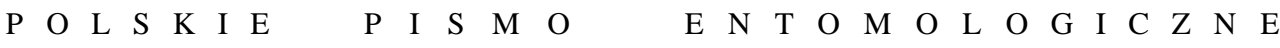

VOL. 86: 293-301

Lublin

31 December 2017

DOI: $10.1515 /$ pjen-2017-0017

\section{Description of the first instar of Diaspidiotus ostreaeformis (CURTIS, 1843) (Hemiptera: Diaspididae)}

\author{
ELŻBIETA PODSIADŁO* \\ Department of Zoology, Warsaw University of Life Sciences SGGW, Ciszewskiego 8, \\ 02-786 Warszawa, Poland
}

\begin{abstract}
The first instar of Diaspidiotus ostreaeformis is described and illustrated. Sexual dimorphism is exhibited. Differences between the first instars of D. ostreaeformis and D. zonatus are discussed.
\end{abstract}

KEY WORDS: Hemiptera, Diaspididae, first instar, morphology, sexual dimorphism.

\section{INTRODUCTION}

This species was described under the name Aspidiotus ostreaeformis by CURTIS (1843). MACGILLIVRAY (1921) erected the genus Quadraspidiotus and placed this species in it. Most authors accepted the interpretation of the genus Quadraspidiotus given by MACGILlivRAY (1921) (ZACHRADNIK 1951, SCHMUTTERER 1959, KosZTARAB \& KOZÁR, 1988). But subsequently, DANZIG (1993) invalidated the genus Quadraspidiotus and placed the species in question in the genus Diaspidiotus BERLESE \& LEONARDI, 1896.

Diaspidiotus ostreaeformis (CURTIS, 1843) is a very common armored scale insect with an almost world-wide distribution. It is a highly polyphagous species, most often living on deciduous trees and shrubs. It mainly inhabits lignified plant parts. Locally it is a serious pest of fruit trees.

\footnotetext{
* Corresponding author: elzbieta_podsiadlo@sggw.pl
} 
D. ostreaeformis is biparental and develops through 3 instars in the female and 5 in the male. In Central Europe, it has 1 annual generation and overwinters as a second instar nymph.

The identification of all the life stages of this species will enable its biology to be studied. The first instar nymphs of $D$. ostreaeformis have not yet been described.

\section{MATERIALS AND METHOD}

First-instar larvae - from newly hatched individuals to fully-grown ones were collected from Malus sp. on 21.07 - 20.08.2009 in Warsaw, and from Betula sp. on 9.08.2009 in the Kampinoski National Park near Warsaw. Slide mounts were made of 21 male specimens and 23 female specimens.

The number of setae and other structures is given for one body half. Measurements (in micrometres $(\mu \mathrm{m}))$ are given as averages followed by ranges in parentheses.

\section{DESCRIPTION}

\section{Male first instar nymph (Figs 1, 3a)}

Live individuals yellow, newly hatched oval in outline (Fig. 1), fully grown variable in shape from broadly oval to nearly circular, usually with triangle-like pygidium (Fig. 3a). Body sizes are given in Table 1.

Pygidial margin. Lobe 2 present on abdominal segment 7, well-developed, sclerotized, unilobed, with 2-3 notches on outer margin and 1 notch on mesal margin, with a basal sclerosis extending inwards from the lobe. Marginal protuberances or processes but without basal scleroses often present posterior to dorsal marginal seta of abdominal segment 6 (see Fig. 2). One simple plate on abdominal segment 8;1-2 simple, bifid or furcate plates on abdominal segment 7 .

Table 1. Body sizes (in $\mu \mathrm{m}$ ) of first-instar nymphs of Diaspidiotus ostreaeformis.

\begin{tabular}{|c|c|c|c|}
\hline \multicolumn{2}{|c|}{ Newly-hatched specimens } & Fully-grown specimens \\
\hline length & width & length & width \\
\hline \multicolumn{4}{|c|}{ First-instar males } \\
\hline $266(260-280)$ & $173(170-175)$ & $389(360-450)$ & $314(280-340)$ \\
\hline \multicolumn{5}{|c|}{ First-instar females } \\
\hline $289(275-300)$ & $183(180-185)$ & $425(420-430)$ & $331(320-342)$ \\
\hline
\end{tabular}




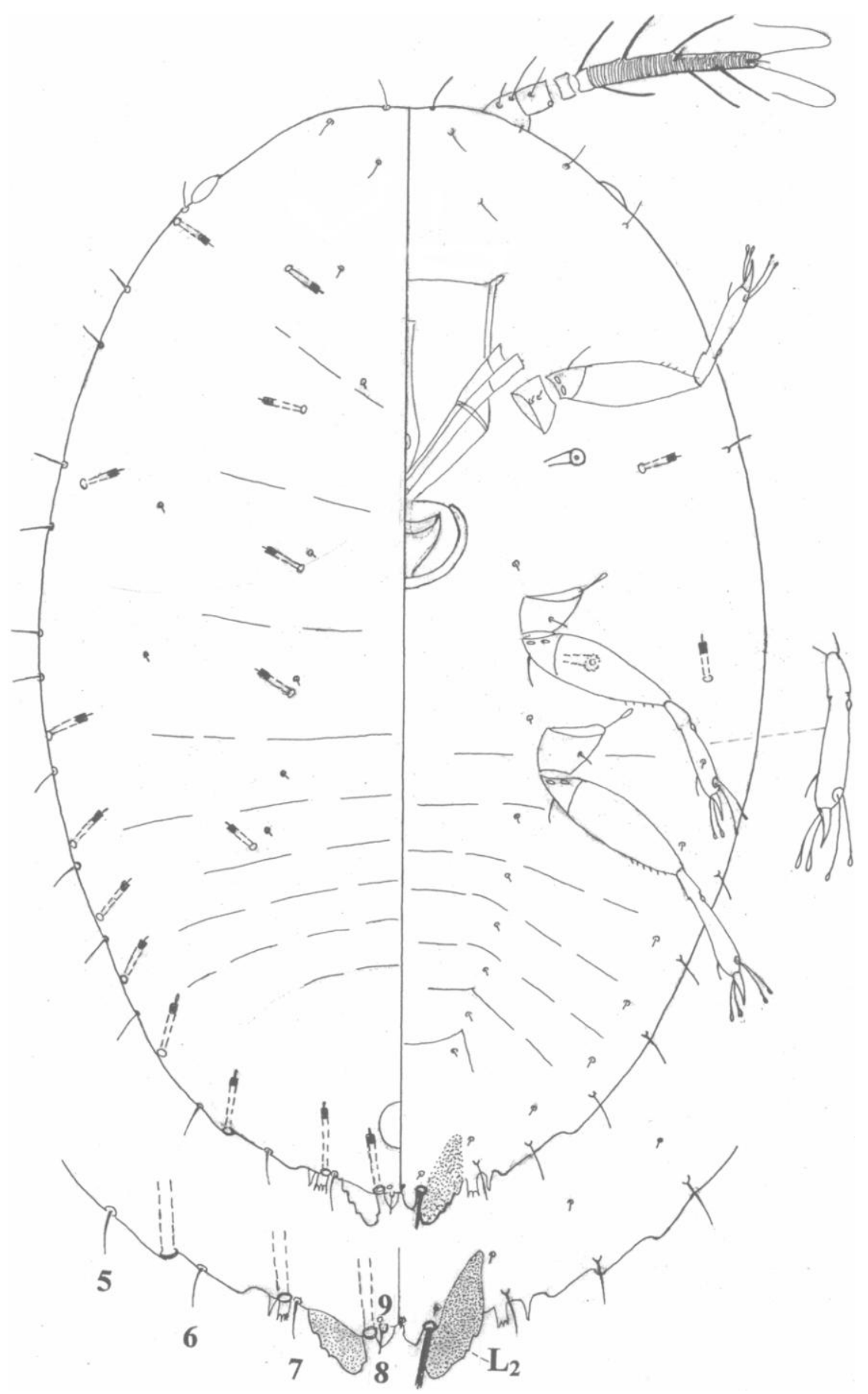

Fig. 1. First-stage male of Diaspidiotus ostreaeformis. 


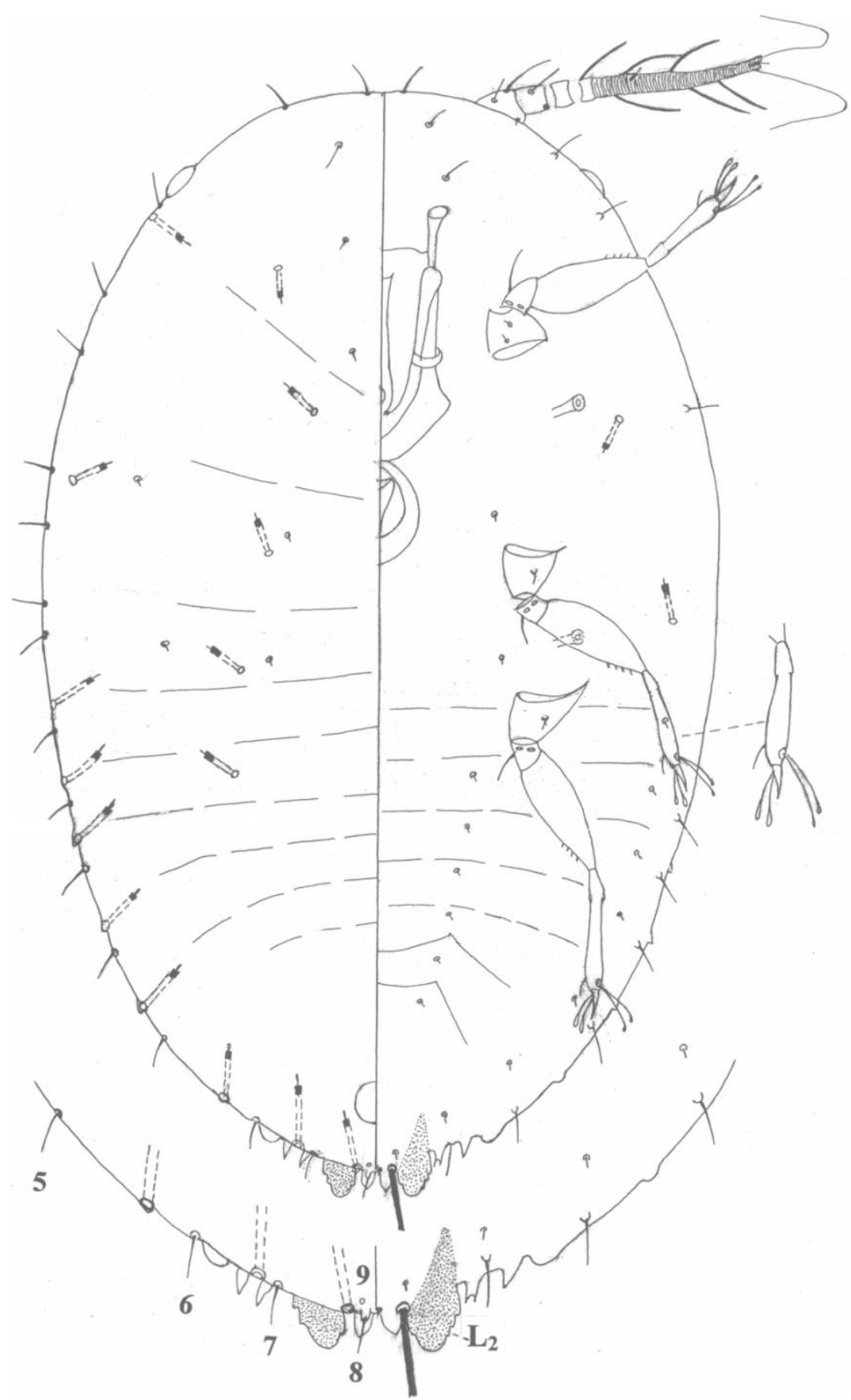

Fig. 2. First-stage female of Diaspidiotus ostreaeformis. 


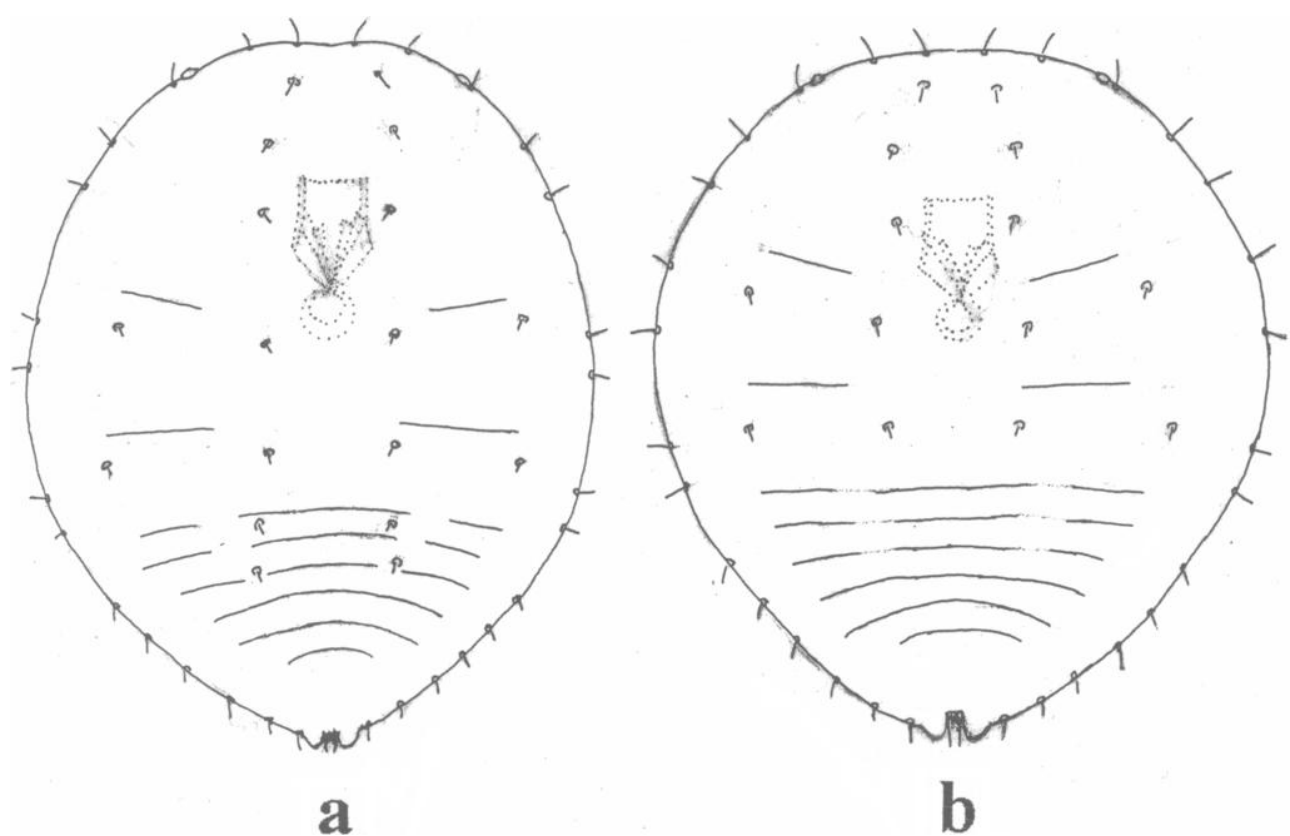

Fig. 3. Fully grown first instar larvae of Diaspidiotus ostreaeformis a - male, $\mathrm{b}$ - female; the dorsal setal patterns distinguish the sexes of the first stage.

Dorsal surface. Head, pro-, meso- and metathorax not clearly marked; abdominal segments 1-4 well-defined by intersegmental dermal furrows; subsequent segments fused to form a pygidium.

Marginal setae: 3 on head, 2 on each thoracic segment, and 1 on each of abdominal segments 1-8. Marginal seta of abdominal segment 9 is placed anteriorly to seta of segment 8. Mesolateral setae: 1 short seta each on meso- and metathorax. Submedian setae: 3 on head, 1 each on meso- and metathorax and 1 on each of abdominal segments 1-2.

Marginal microducts: 1 on head near eye and 1 on each of abdominal segments 1-8. Submarginal microducts: 1 on mesothorax. Submedian microducts: 1 on head, 1 on each thoracic segment and 1 on abdominal segment 2 .

Anal opening broadly oval, av. $12.5 \times 11.2 \mu \mathrm{m}$, located at a distance of about 1 times its length from the posterior margin.

Ventral surface. Head, pro-, meso- and metathorax nearly fused; abdominal segments $1-5$ well defined by intersegmental dermal furrows; the subsequent segments fused to form a pygidium. 
Antennae 5-segmented, the fifth segment being the longest. Dimensions given in Table 2. Segment I with 1 short basal, 1 medial sub-basal, and 1 long apical slender setae. Segment II with 1 long slender seta and an apical sensorium. Segment III without setae. Segment IV with 1 stout seta. Segment V annulated with 5 stout setae, 2 very long terminal setae ( 1 on each of the two apical projections) and 2 invaginated minute setae located between apical projections and near the middle of segment $\mathrm{V}$.

Table 2. Measurements (in $\mu \mathrm{m}$ ) of antennae and legs in the first-instar nymphs of Diaspidiotus ostreaeformis.

\begin{tabular}{|c|c|c|}
\hline Character & Male first instar & Female first instar \\
\hline Antenna: total length & $66.9(61.5-72.5)$ & $72.7(63.5-76.0)$ \\
\hline length of $1^{\text {st }}$ segment & $8.9(7.5-12.5)$ & $9.8(7.5-12.5)$ \\
\hline length of $2^{\text {nd }}$ segment & $8.2(7.5-10.0)$ & $9.6(8.5-10.0)$ \\
\hline length of $3^{\text {rd }}$ segment & $4.3(3.0-6.0)$ & $4.8(3.5-5.0)$ \\
\hline length of $4^{\text {th }}$ segment & $3.7(3.0-5.0)$ & $3.4(2.5-3.5)$ \\
\hline length of $5^{\text {th }}$ segment & $41.7(40.0-43.5)$ & $45.0(37.5-47.5)$ \\
\hline Leg I: total length & $79.0(72.5-85.0)$ & $88.6(82.0-92.0)$ \\
\hline length of coxa & $13.7(12.5-15.0)$ & $12.9(12.5-15.0)$ \\
\hline length of trochanter + femur & $34.8(32.5-37.5)$ & $39.8(37.5-45.0)$ \\
\hline length of tibia & $7.2(6.0-7.5)$ & $8.8(7.5-10.0)$ \\
\hline length of tarsus & $14.7(12.5-17.5)$ & $17.7(16.0-20.0)$ \\
\hline length of claw & $8.6(7.5-10.0)$ & $9.2(7.5-10.0)$ \\
\hline Leg II: total length & $82.5(76.0-86.0)$ & $91.9(89.0-96.0)$ \\
\hline length of coxa & $14.1(12.5-15.0)$ & $13.2(12.5-13.5)$ \\
\hline length of trochanter + femur & $36.4(35.0-39.0)$ & $41.5(40.0-42.5)$ \\
\hline length of tibia & $7.2(6.0-7.5)$ & $9.4(7.5-11.0)$ \\
\hline length of tarsus & $15.6(12.5-17.5)$ & $18.0(16.0-20.0)$ \\
\hline length of claw & $9.2(7.5-10.0)$ & $9.7(8.5-10.0)$ \\
\hline Leg III: total length & $87.9(81.5-91.0)$ & $99.0(93.5-102.5)$ \\
\hline length of coxa & $14.7(12.5-15.0)$ & $14.3(12.5-15.0)$ \\
\hline length of trochanter + femur & $37.2(35.0-40.0)$ & $42.8(40.0-45.0)$ \\
\hline length of tibia & $8.0(6.5-10.0)$ & $9.6(7.5-12.5)$ \\
\hline length of tarsus & $17.8(15.0-20.0)$ & $21.7(20.0-22.0)$ \\
\hline length of claw & $10.2(10.0-11.0)$ & $10.6(10.0-11.0)$ \\
\hline
\end{tabular}


Clypeolabral shield 63.9 (62.5-65.0) $\mu \mathrm{m}$ long, 38.6 (37.5-40.0) $\mu \mathrm{m}$ wide. Labium onesegmented, 25.0 (22.5-27.5) $\mu \mathrm{m}$ long, 30.0 (27.5-32.5) $\mu \mathrm{m}$ wide. No setae visible.

Legs well developed, slightly increasing in size from anterior to posterior pair. Dimensions given in Table 2. Coxa I with 1 seta on dorsal and 2 on ventral side. Coxa II and III with 1 seta on dorsal and 1 on ventral side. Trochanter with 2 sensilla on each side and 1 elongated seta. Femur without setae but with a row of toothlike structures on posterior margin. Tibiotarsal septum not visible in young individuals, but often noticeable in fully-grown ones. Tarsus with a campaniform sensillum near its base, 1 subapical seta and 2 knobbed apical digitules longer than claw. Claw with 2 knobbed digitules exceeding its length.

Meso- and metathoracic spiracles present. Mesothoracic spiracles displaced anteriorly on prothorax.

Marginal setae: 3 on head, 1 on prothorax and 1 on each of abdominal segments 2-9. Marginal seta of $8^{\text {th }}$ abdominal segment, the so-called "apical seta" very long, up to 165 $\mu \mathrm{m}$. Submarginal setae: 1 on each of abdominal segments 1-8. Submedian setae: 2 on head anterior to clypeolabral shield, 1 on each meso- and metathorax and 1 on each of abdominal segments 2-7.

Microducts: 1 submarginal duct located posterolaterad to anterior spiracle and 1 on metathorax.

\section{Female first-instar nymph (Figs 2, 3b)}

Similar to male, but differs distinctly in the absence of the campaniform sensillum near the base of the tarsus and in the absence of the pair of dorsal submedian setae on the first and second abdominal segments. Measurements of body, antennae and legs are given in Tables 1 and 2.

\section{NOTES}

The sexual dimorphism of first-instar nymphs in Diaspididae is well known. StOETZEL \& DAVIDSON (1974a, 1974b) noticed the setal pattern by which the sexes can be distinguished in all stages of the Aspidiotini tribe. They stated that all male stages possess a pair of dorsal submedian setae on the first and second abdominal segments, whereas these setae are missing in female instars. All the examined male nymphs of $D$. ostreaeformis possessed a pair of dorsal submedial setae on the $1^{\text {st }}$ and $2^{\text {nd }}$ abdominal segments (Fig. 3a); moreover, 1 specimen had 1 seta on one half of the $3^{\text {rd }}$ abdominal segment, and another specimen 1 seta on one half of the $4^{\text {th }}$ abdominal segment. These setae were absent in all the female nymphs examined (Fig. 3b). Howell \& TIPPINGS (1977) found a tarsal 
campaniform sensillum in all male larvae of eight diaspidid tribes, but in female larvae only in some of those tribes. D. ostreaeformis belongs to the group in which the females have no sensillum.

In Poland D. ostreaeformis has been recorded from numerous host plants (KоTEJA 1996). It was also found on oaks together with D. zonatus (FRAUENFELD, 1868) (PoDSIADEO 2006). Since the first instar nymphs of D. zonatus were described earlier (PoDSIADŁo 1997), the present study makes it possible to distinguish the first instars of these two species.

Constant characteristics distinguishing the first instars of these two species appear to be:

In D. ostreaeformis: (1) one basal sclerosis extending inwards from $\mathrm{L}_{2}$, (2) ventral abdominal submedian setae present on segments 2-7, (3) ventral abdominal marginal setae present on segments 2-9, (4) ventral submarginal duct present on metathorax.

In D. zonatus: (1) two basal scleroses extending inwards from $\mathrm{L}_{2}$ and $\mathrm{L}_{3}$, (2) ventral abdominal submedian seta present on segment 7, (3) ventral abdominal marginal setae present on segments 5-9, (4) ventral submarginal duct absent on metathorax.

\section{REFERENCES}

Berlese A., Leonardi G. 1896. Diagnosi di Cocciniglie nuove. Rivista di Patologia Vegetale 4: $345-352$.

CURTIS J. (RURICOLA) 1843. Aspidiotus ostreaeformis (the pear-tree oysterscale). Gardeners' Chronicle 46: 805.

DANZIG E.M. 1993. Scale insects (Coccinea). Families Phoenicoccocidae and Diaspididae. Russian Academy of Sciences, Zoological Institute, St. Petersburg. (in Russian)

Howell J.O., TipPINGS H.H. 1977. Descriptions of first instars of nominal-type species of eight diaspidid tribes. Annals of the Entomological Society of America 70:119-135.

Kosztarab M., KozÁr F. 1988. Scale insects of Central Europe. Akadémiai Kiadó, Budapest.

Koteja J. 1996. How to recognize scale insects (Homoptera, Coccinea). [in:] J. BoczeK (ed.). Diagnostics of plant pests and their natural enemies, II. Wydawnictwo SGGW, Warszawa, 139-231. (in Polish)

MaCGillivRay A.D. 1921. The Coccidae. Urbana, Illinois.

PodsiadŁo E. 1997. Morphology of the first instar of Quadraspidiotus zonatus (FRAUENFELD) (Homoptera, Coccinea, Diaspididae). Annales Zoologici 46(3-4): 193-200.

Podsiadeo E. 2006. Hints for the identification of the species of Quadraspidiotus MacGillivray, 1921 (Hemiptera: Coccinea: Diaspididae) occurring on oaks in Poland. Wiadomości Entomologiczne 25(1): 15-19. (in Polish)

SCHMUtTERER H. 1959. Die Tierwelt Deutschlands und der angrenzenden Meeresteile, Teil 45. Schildläuse oder Coccoidea. I. Deckelschildläuse oder Diaspididae. Fischer Verlag, Jena. 
Stoetzel M.B., Davidson J.A. 1974a. Sexual dimorphism in all stages of the Aspidiotini (Homoptera: Diaspididae). Annals of the Entomological Society of America 67: 138-140.

StoetZel M.B., DAVIDSON J.A. 1974b. Biology, morphology and taxonomy of immature stages of 9 species in the Aspidiotini (Homoptera: Diaspididae). Annals of the Entomological Society of America 67: 475-509.

ZACHRADNIK J. 1951. Revision der Čechoslovakischen Arten der Schildläuse aus der Unterfamilie der Diaspidinae. Acta Entomologica Musei Nationalis Pragae 27: 89-200.

Received: 5 May 2017

Accepted: 6 July 2017 